\title{
Exchange Rate And Asean Share Price: An Analysis Of Asimmetry Response
}

\author{
Nyoman Suprastha and Yanuar \\ Fakultas Ekonomi Universitas Tarumanagara \\ Email: nyomasnsuprastha54@gmail.com,yanuar@fe.untar.ac.id
}

\begin{abstract}
The purpose of this study is to examine whether these markets react differently to market upturns and market downturns of markets using VAR models. This study finds that following:. First, in line with many studies on international interdependencies of equity prices,. Second, the evidence strongly suggests significant responses of the ASEAN markets to the US exchange rate downturns Third, the pattern of responses based on impulse response functions further substantiate asymmetric responses of these markets to positive and negative shocks in the US exchange rate. Practical implications, suggest that the benefits of international portfolio diversification. The originality of study is exchange rates US have an impact on ASEAN stock market integration.
\end{abstract}

Keywords: VAR models, impulse response, asymmetric responses.

\section{INTRODUCTION}

The financial crisis that emerged in the United States in 2007 and spread in 2008 was one of the worst, because it had a tremendous negative impact on the capital market (TP Thao \& Daly, 2012), however, most of the ASEAN member countries could isolated from the immediate impact of the crisis, because ASEAN countries had experienced a crisis during the Asian financial crisis in 1997. Finally, ASEAN countries agreed to succeed in the international market, so each country took a policy to prioritize macroeconomic stability, paying attention to signals in the micro context appropriately, and paying attention to the infrastructure as a whole, as well as the development of the private sector, all of which are expected so that ASEAN countries can compete.

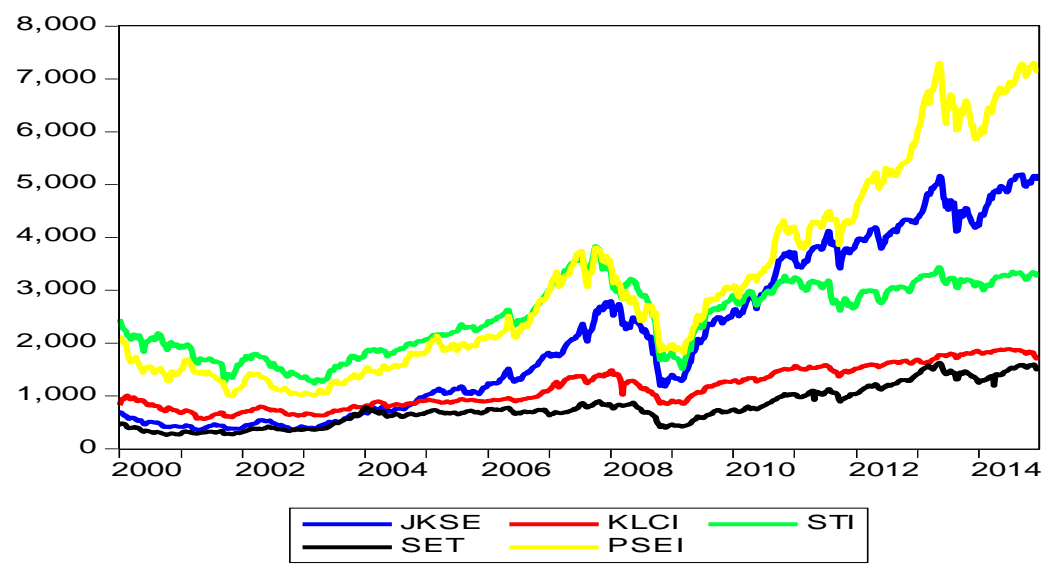

Figure 1. Development of the ASEAN-5 Capital Market Index 2010 - 2014 
Based on figure 1, above that at the beginning of the research period, the highest index in 2000 was the Singapore stock index (STI), which ranged above 2000 points, the second was the Philippine stock index, after that the Malaysian index (KLCI), and the lowest is the Indonesian index (JKSE) and the Thai index (SET). Along with the development of time, each of the five ASEAN countries' capital market indices also experienced fluctuating developments until 2003. After 2003 to 2007, almost all capital markets experienced increased performance, but in 2008 all experienced a decline. This can be understood because in 2007 there was a United States financial crisis, where almost all shares throughout the world declined. Besides that, there was also an increase in world oil prices, which had a slight effect on the ASEAN economy.

\section{THEORETICAL REVIEW}

Financial market globalization refers to the increasing economic integration in specialization and economies of scale, which will result in greater trade in financial services through capital flows and cross-border activities. But another impact of Globalization was that it could create a crisis, which can be seen from the crisis in 1998, at that time the Thai government left the exchange rate benchmark on July 2, 1997, a move that caused the Thai baht to plunge $15 \%$ against the US dollar. The incident caused panic for other Southeast Asian countries, especially Malaysia, Indonesia and the Philippines. The impact was in the July and August 1997 periods, the Philippine peso, the Indonesian rupiah and the Malaysian Ringgit depreciated. In less than a year, the Asian financial crisis quickly spread and was felt by almost all countries in the Asian region (Goh et al., 2005).

Trade factors and monetary conditions play an important role in creating a crisis (Chen and Chen, 2012), then according to monomer policy is the main contribution compared to trade relations in explaining the possibility of falling currencies so as to create a crisis. In order to overcome this, monetary policy must stabilize currency exchange rates to attract foreign investors. By carrying out Copula-based dependency measures to help foreign investors and recipients of investment in a country to change related strategies and policies; then they will be able to maximize their utility functions (Kamal and Haque, 2016).

(Abdul Karim and Xin Ning, 2013) found out about bilateral trade ties which hold that the stronger the bilateral trade ties between countries, the higher the level of joint movement. In addition, if the volatility of a market increases relative to other market volatility, the first market return must also increase relative to the second market return. Another study conducted by (Karim and Ning, 2013), found out that the volatility of trade and stock markets significantly affected the integration of stock markets in the ASEAN-5 region.

After the Asian crisis, in a period of ten years a new crisis emerged, namely the subprime mortgage crisis, often called the global crisis. Mutual dependence is the source of the subprime mortgage crisis, and the result of recent studies showed that the distribution of the crisis affects financial market integration with a high degree of correlation in the long run. The theoretical literature on the impact of transmission of the crisis is actually still relatively new. Study results from (Masson, 1999) mentioned that contribute to understanding transmission from the crisis. It can be concluded that crisis transmission can be carried out with the main approach, namely to identify shock 
transmission channels in the absence of fundamental economic relations between countries. Investors can apply lessons learned aftershocks in one country to another with similar macroeconomic structures and economic policies. For example, if a country with a relatively weak financial system faces a crisis, investors can review the strength of the banking system of other countries and adjust their probability of the crisis plan. The relationship between the stock index returns will be measured by their correlation coefficient (Majdoub and Mansour, 2014).

There is something quite interesting to note about the 2008 global crisis, that ASEAN members showed a very different response to the crisis, compared to responses from developed countries. This was seen from the agreement for ASEAN countries by holding a summit in Chiang Mai Thailand in early 2009 when all ASEAN members pledged to fight protectionism.

Besides that, it is also interesting to note the result of a study from (Tran Phuong Thao et al., 2013) on the Impact of the Global Financial Crisis on Southeast Asian Equity Market Integration, mentioned that where they examine long-term relationships among six equity markets in the Southeast Asia region. Namely Thailand, Malaysia, Singapore, Philippines, Indonesia and Vietnam using the daily market index collected during the period 2006 - 2010. With the aim of revealing empirical evidence about long-term relationships between Southeast Asian equity markets with a view to understanding the possible impact of the Financial Crisis Global. Three test methods are used, namely; bivariate co-integration test based on residual, multivariate co-integration test based on autoregressive vector (VAR) model and co-integration test with structural termination. The result reveals that there is evidence that there is a long-term relationship between these markets. This result has the implications for investors in this market in terms of risk diversification and returns where shocks to one market are likely to have a contagious effect on other markets in the region ASEAN.

Based on observations of several researchers about ASEAN stock market integration basically not fully showing the uniformity of results, including the result of research from (Click and Click, 2003), where they both conducted research after the 19971998 ASIA financial crisis against 5 State Association Members Southeast Asian countries (ASEAN). A study from Click, Plummer considered the extent of the five ASEAN stock markets (ASEAN-5) such as Indonesia, Malaysia, Philippines, Singapore and Thailand and with data consisting of daily stock price indexes in the eyes local money for a period of four and a half years from 1 July 1998 to 31 December 2002, with a total of 1175 observations using time series co-integration techniques to extract long-term relationships. Empirical result showed that ASEAN-5 stock markets are co-integrated and thus not fully segmented by borders. Adopting co-integration procedures (Baillie and Bollerslev, 1994) and weekly data from January 1981 to December 1991, they found out that there are at least three co-integration vectors between five equity markets during 1981-1991. However, there was no co-integration evidence in the first sub-period 1981-1987. Therefore, the benefits of international diversification by investing in these markets may be limited. In contrast, using multivariate co-integration and the Granger causality test with weekly data from 1988 to 199 (Dillistone et al., 2010) found evidence showing non co-integration vectors among the five stock markets of the Association of Southeast Asian Nations (ASEAN). However, in the short term, with the exception of Indonesia, these markets show significant interactions. Malaysia is found to be the most 
influential market, while Singapore and Thailand are markets with most relationships with other markets. Utilizing weekly data from January 1988 to August 1999 and co-integration and Granger non- catalytic tests (Toda and Yamamoto, 1995) examined whether causality exists between the ASEAN-5 stock markets (Indonesia, Malaysia, Philippines, Singapore and Thailand) in the long run. They found that Singapore's equity markets were not affected by other markets except by the Philippines in the long run. In addition, there is no ASEAN market that is influenced by Indonesia, consistent with (Roca et al., 1998).

The relationship between international stock markets has become increasingly important since analyzing the benefits of international diversification. Since then many researchers have studied this relationship in an international context. Like (Kumar, 2016) examined the phenomenon of market integration in accordance with stated of monetary policy, focusing on the effectiveness of monetary policy and the level of market integration in G7 countries. By applying regression models they found out the significant evidence that monetary policy influences long-term interest rates that affect international interdependence between capital markets.

The issue of capital market integration in Southeast Asia has been studied, specifically using co-integration techniques. The main problem is discussed whether the individual stock market is very (positively correlated), although recently the problem has been rearranged to overcome "transmission" across the market. There are several other aspects that are examined as part of a common problem, among others, are:

First consider what econometric techniques are appropriate for examining the correlation between stock markets.

The second aspect is the use of time periods, the opening of the stock exchange is not the same in each country, and whether there are changes over time such as market convergence or structural breaks or shifts in relationships (such as those related to equity market liberalization or financial crises).

The third is whether empirical analysis must be carried out in local currency, US dollar, Japanese yen, or several other units. The fourth is whether the local market is influenced by the US market, or the Japanese market, or both of them. Overall, the conclusions in the literature on Southeast Asian stock market integration still seem contradictory. This may be partly due to different methodologies, even when using cointegration techniques (Click and Click, 2003).

Basically there are two main definitions for stock market integration, which will be adopted in this study. Associated with a long-developed theoretical model (i.e. Pricing Capital Asset Model "CAPM"), according to this model, national markets are considered integrated, if there are the same risk characteristics and at the same price, where if the shares are traded in different markets. In other words, if two or more markets are integrated, it must have identical prices in both markets. The existence of stock market integration showed that stocks in all markets are exposed to the same risk factors and the risk premium on each factor is the same in all markets. 


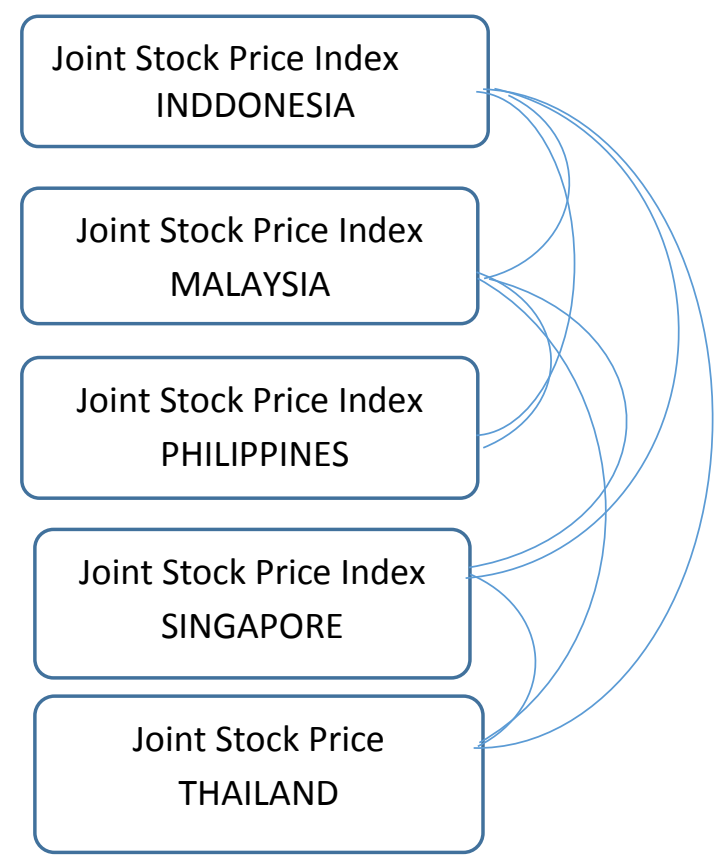

Figure 2 : Conceptual Framework

Hypothesis. Based on the formulation of research problems and underlying theories, the research hypothesis can be formulated as follows:

H1: There is capital market integration in the ASEAN region

$\mathrm{H} 2$ : There are capital markets in the ASEAN region where each capital market influences and is influenced by other capital markets significantly.

\section{METHODOLOGY}

Then, we adopt framework vector autoregressive (VAR) to examine asymmetry in the ASEAN market's response to moving exchange rate changes. Basically, the VAR model is a system of reduced form equations that treats all variables in the system as potentially endogenous. The main advantage is that it captures empirical regularities in data with minimal theoretical restrictions imposed on the system. The formulation of the VAR model is written as follows:

$$
\mathrm{Z}_{\mathrm{t}}=\mathrm{A}_{0}+\sum \mathrm{A}_{\mathrm{k}} \mathrm{Z}_{\mathrm{t}-\mathrm{k}}+\boldsymbol{E}_{\mathrm{t}}
$$

Where $Z_{t}$ is a variable vector consisting of positive and negative returns from an ASEAN Market,

While model estimation is based on equation (1), the coefficient estimation is not very useful for conclusions. Usually, the interpretation of VAR is based on the representation of the moving average. With successive replacements or replacements, the VAR model (2) has the following average representation movements: 
$\mathrm{Zt}=\mathrm{B}+\sum \mathrm{B}_{\mathrm{k}} \boldsymbol{\varepsilon}$

Thus, $\mathrm{Zt}$ is expressed as a linear combination of current and past innovation. Based on the model above, then impulses can be generated. Basically, impulse response functions (IRF) trace the variable direction responses to a standard deviation shock in another variable. Thus, from the IRF, we can note the response pattern of ASEAN equity markets to increase and decrease in international stocks.

Data. The data used in the analysis is weekly from January 2000 to December 2014. We use weekly data instead of higher frequency data such as daily data for the following reasons. High frequency data such as daily data contain too much noise and are subject to unsynchronized and infrequent trading problems, which can lead to incorrect conclusions in the lead-lag relationship between variables. In addition, the issue of securities on Saturdays and Sundays is usually inherent in daily data. For weekly data, we need to choose one day a week to represent the weekly price.

The ASEAN markets discussed in this study are those consisting of five founding members of ASEAN, namely, Indonesia, Malaysia, the Philippines, Singapore and Thailand. The index data is used to represent ASEAN markets and the United States exchange rates such as the following: Jakarta Composite Index for Indonesia (JKSE), Kuala Lumpur Composite Index (KLCI) for Malaysia, PSE Composite Index for Philippines, Singapore Index (STI) and SET Index for Thailand. Whereas the international market included in the analysis is the US exchange rate.

As a basis for model specifications, all indexes are first tested in the unit root test and co-integration. To save space, these results are not reported. But from the test result it was found that all indexes were not integrated and based on the commonly used ADF and PP unit root tests. Moreover, using (Johansen., 1988) and (Johansen and Juselius., 1990) co-integration tests, did not find support for the co-integration presence between each ASEAN market, and the US market.

Thus, the model described in the previous section, where we use market returns in analysis, can be justified. 


\section{Stages of Analysis}

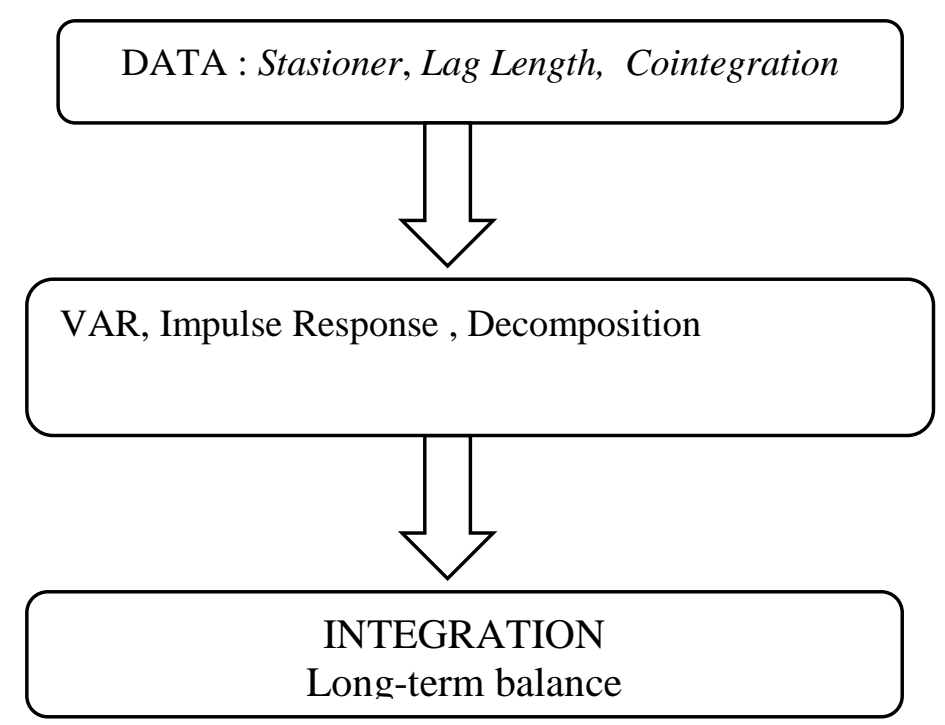

Figure 3: Stages of Analysis

\section{ANALYSIS AND DISCUSSION}

Table 1. Correlation of the ASEAN-5 stock index

\begin{tabular}{cccccc}
\hline & JKSE & KLCI & SET & STI & PSEI \\
\hline \hline JKSE & 1.000000 & 0.980110 & 0.948295 & 0.842240 & 0.974480 \\
KLCI & 0.980110 & 1.000000 & 0.936570 & 0.895183 & 0.964821 \\
SET & 0.948295 & 0.936570 & 1.000000 & 0.801325 & 0.961454 \\
STI & 0.842240 & 0.895183 & 0.801325 & 1.000000 & 0.825273 \\
PSEI & 0.974480 & 0.964821 & 0.961454 & 0.825273 & 1.000000
\end{tabular}

Based on Table 1 above it can be seen that there is a very strong correlation between the five stock indexes, the strongest is the correlation between JKSE and KLCI which is equal to 0.98 (very strong), as well as between KLCI and PSEI of 0.96 and between JKSE and SET is 0.95 , the smallest among them is the correlation between JKSE and PSEI of 0.84 , the rest are all correlations between 0.90 and above. It can be concluded from the results of the correlation, that there is a very strong and positive relationship between the five Indonesian, Malaysia, Singapore, Thailand and Singapore stock indexes, thus supporting the presentation of previous data that there is an indication of the integration of the five shares from the 2000 to year 2014.

The level of significance between variables. In the VAR model, it is assumed that all variables are interdependent with each other, although in essence the VAR model, all exogenous and endogenous variables that are believed to be interconnected should be included in the model. But it can also include exogenous variables in VAR (Widarjono, 2007), in this study Dow Jones Index is categorized as exogenous. 
Conclusion of the Equation of the Movement of the Stock Price Index. This study utilizes the Dow Jones Industrial Average (DJIA) index as an exogenous variable in the VAR system; therefore the system can be called Vector Auto regression with Exogenous Variable (VAR-X). Exogenous variables in the VAR system have the meaning that these variables should not be influenced by other variables in the VAR system.

The utilization of the DJIA as an exogenous variable is reasonable, considering that the DJIA is the highest performing index on the New York Stock Exchange (NYSE), and its movements are often used as a reference or guideline for global investors. The conclusion of this study is none of the 5 stock price index equations in ASEAN are not significantly affected by the DJIA. This indicates the contagion effect of the economic performance of the United States indirectly transmitted through the performance of its capital markets to other capital market markets in 5 ASEAN countries.

Impulse Response Analysis. Response from DJKSE. Based on Figure 3 above, it can be concluded that the shock of one standard deviation in DKLCI, DPSEI, DSTI, DSGD, DTHB, DMYR and DPHP, was responded to by the DJKSE, in a two-week period, after the shock occurred, while the shock was one the standard deviation on the DSET and DIDR was responded to by the form of the increase by the DJKSE, in the period two weeks after the shock occurred. After two weeks of balance and after the seventh week the index has recovered as before the shock occurred.

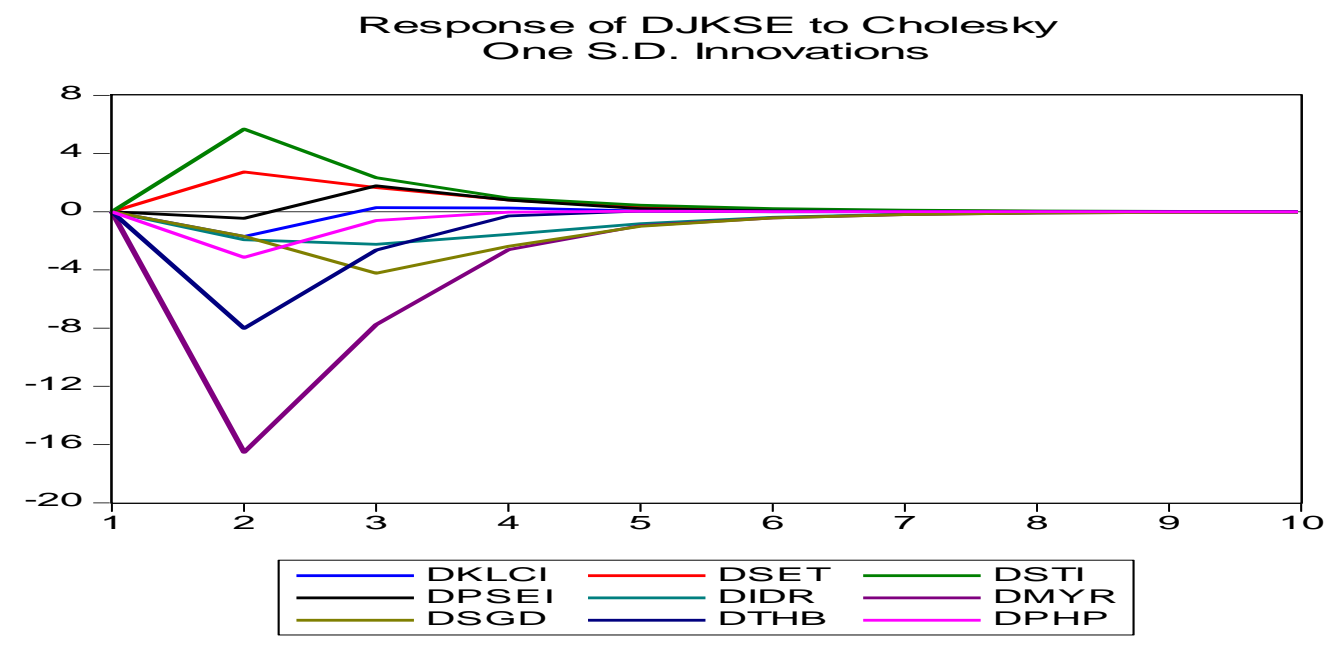

Figure 3. DJKSE response 


\section{Response from DKLCI}

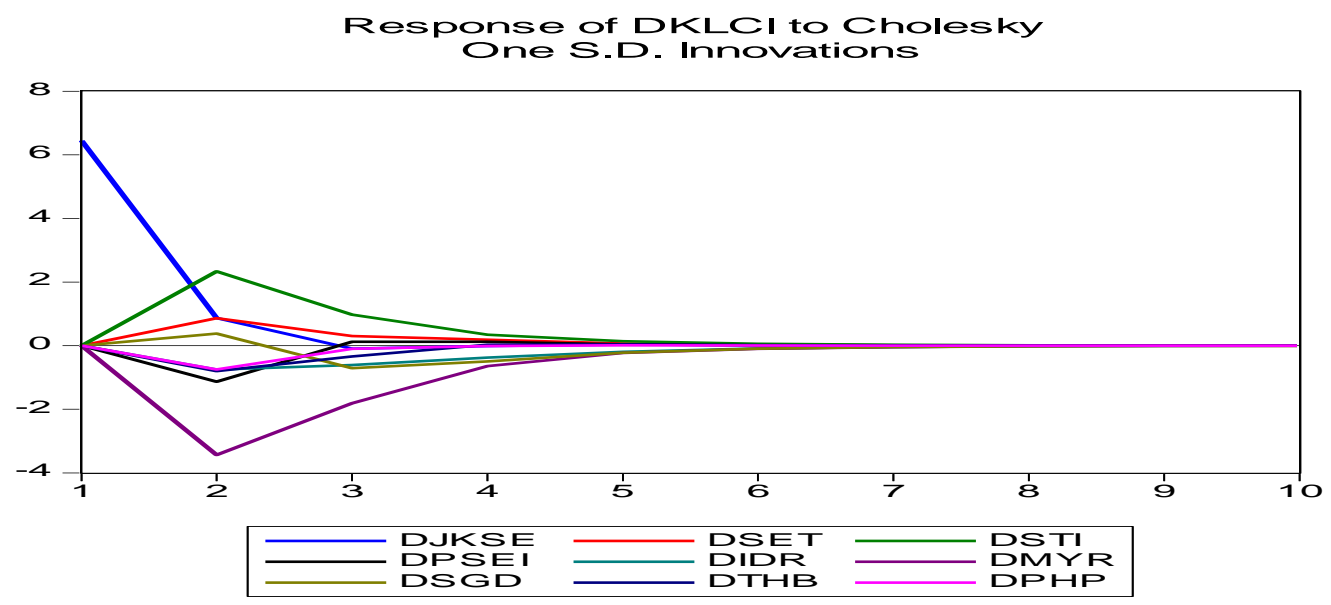

Figure 4. DKLCI Response

Based on figure 4 above that there is a shock from one standard deviation in the DJKSE, DPSEI, DSGD, DTHB, DMYR and DPHP which responded to by a decrease of DKLCI in the period two weeks after the shock occurred. After a two-week period all indexes go to balance in the seven-week period.

\section{Response from DSET}

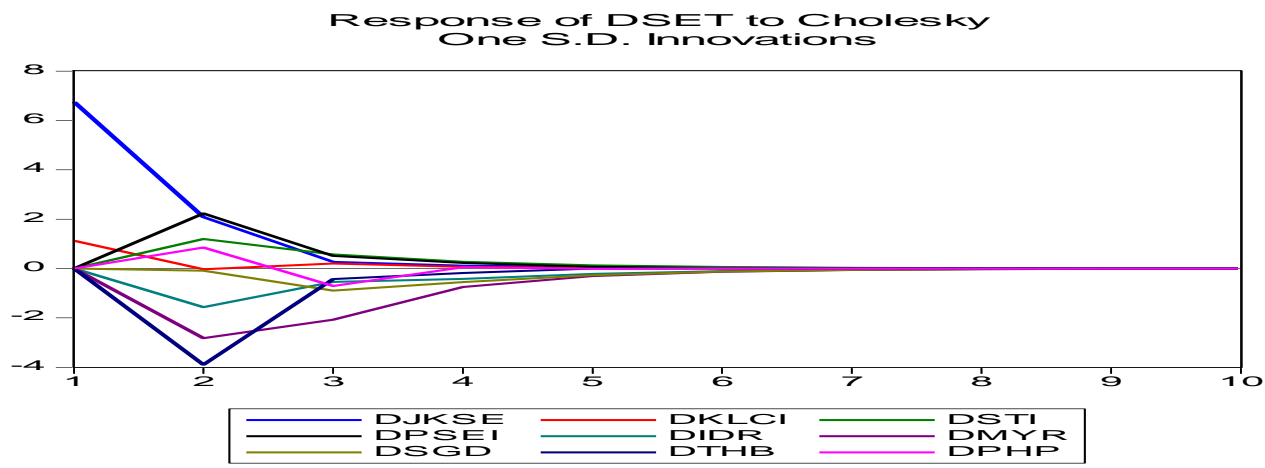

Figure 5. DSET response

Based on figure 5 above it can be concluded that there is a shock of one standard deviation from DPHP, DIDR and DSTI responded by DSET in a period of two weeks after the shock All indices and exchange rates reach balance or return to their original state (before shocks) in the period of week seventh. 


\section{Response from DSTI}

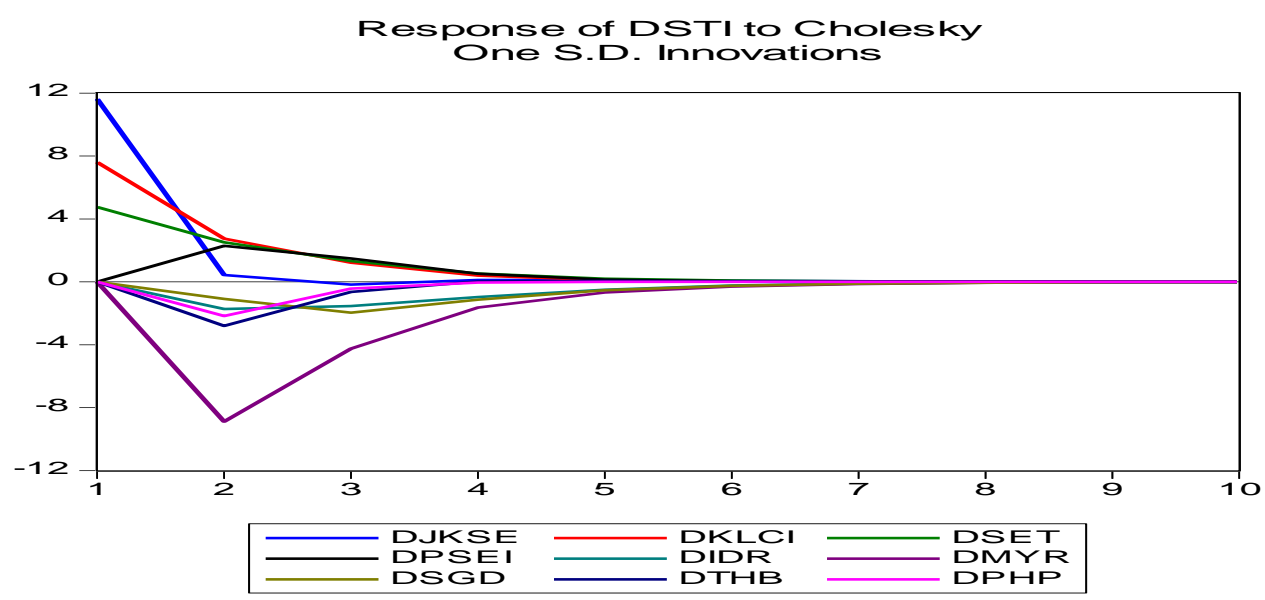

Figure 6. DSET response

Based on figure 6 above, it can be concluded that the existence of a shock of one standard deviation from the DPSEI is responded to by DSTI in the period two weeks after the shock occurred. All indexes and exchange rates reach balance or return to their original state (before shocks) in the seventh week period.

\section{Response from DPSEI}

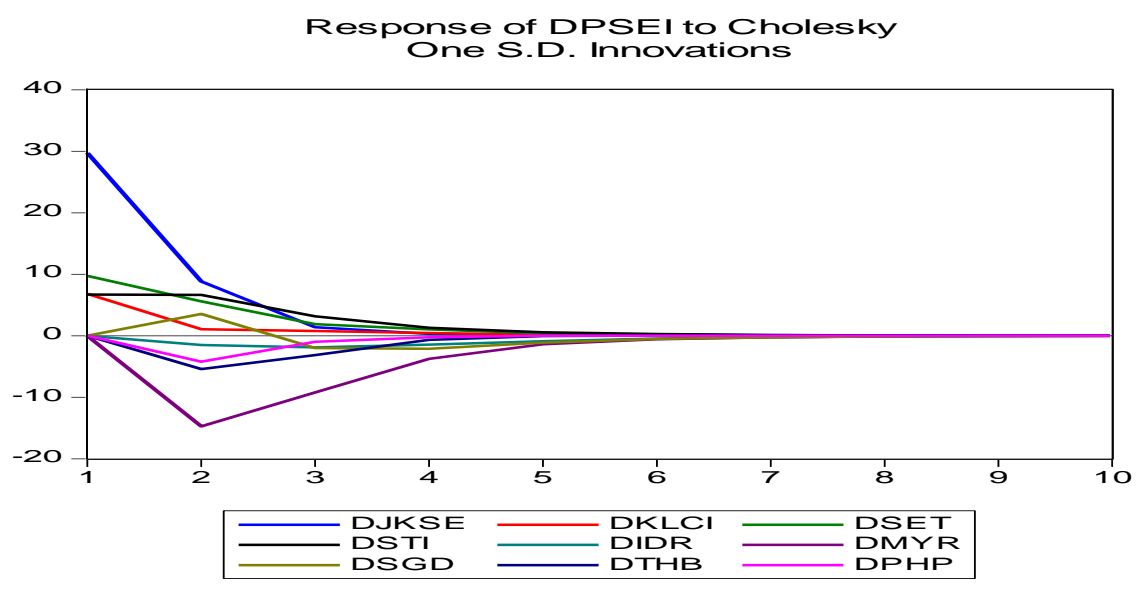

Figure 7. DPSEI response

Based on Figure 7 above it can be concluded that the existence of a shock of one standard deviation from DSTI, DSGD, was responded to by the Philippine stock index DPSEI in the period two weeks after the shock occurred. All indices and exchange rates reach balance or return to their original state (before shocks) in the seventh week period. 


\section{Response from DIDR}

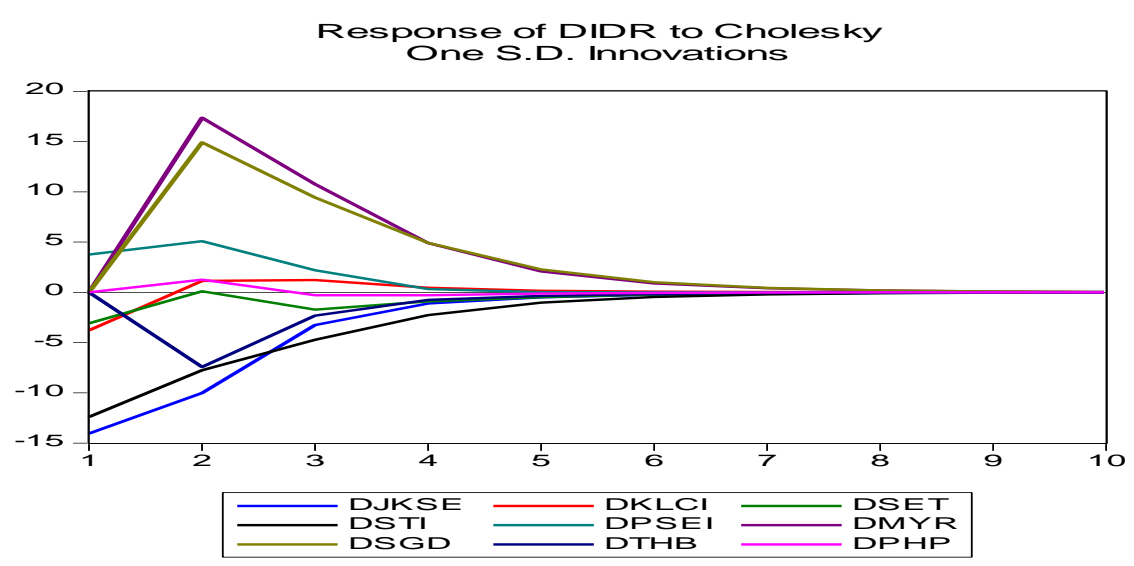

Figure 8. DIDR response

Based on Figure 8 above it can be concluded that there is a shock of one standard deviation from the DJKSE, responded to by the Indonesian exchange rate (DIDR) in the two weeks after the shock All indices and exchange rates reach balance or return to their original state (before shocks) in the eight week period

\section{Response from DMYR}

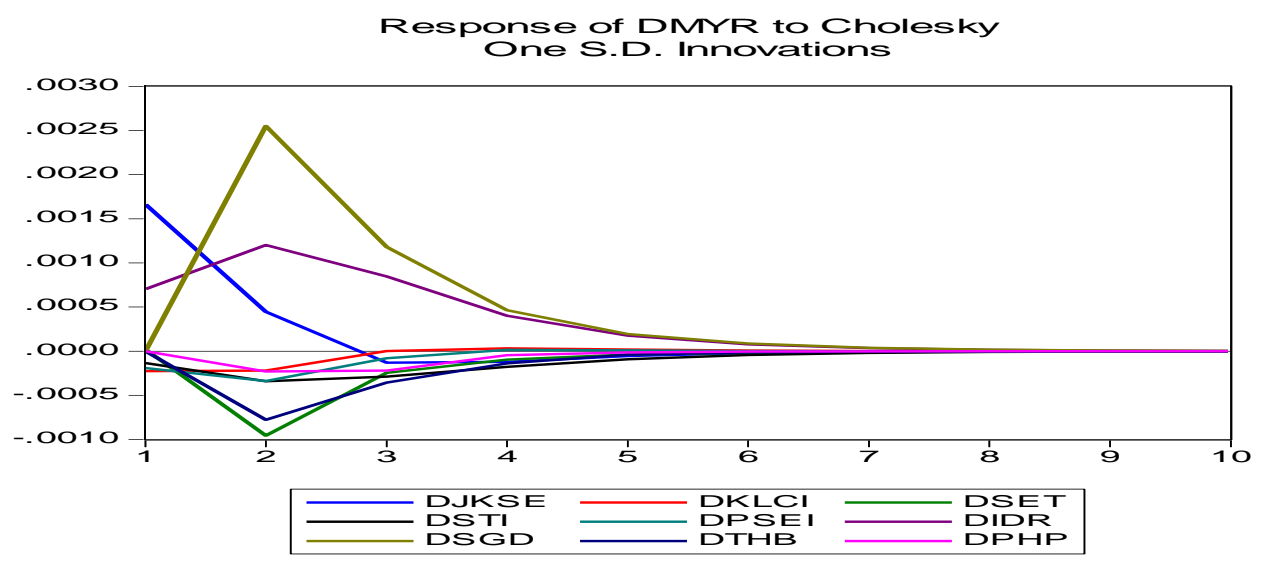

Figure 9. DMYR response

Based on Figure 9 above it can be concluded that there is a shock of one standard deviation from DIDR and DSGD, responded to by the Malaysian exchange rate (DMYR) in the two-week period after the shock occurred. All indices and exchange rates reach balance or return to their original state (before shocks) in the eighth week period. 


\section{Response from DTHB}

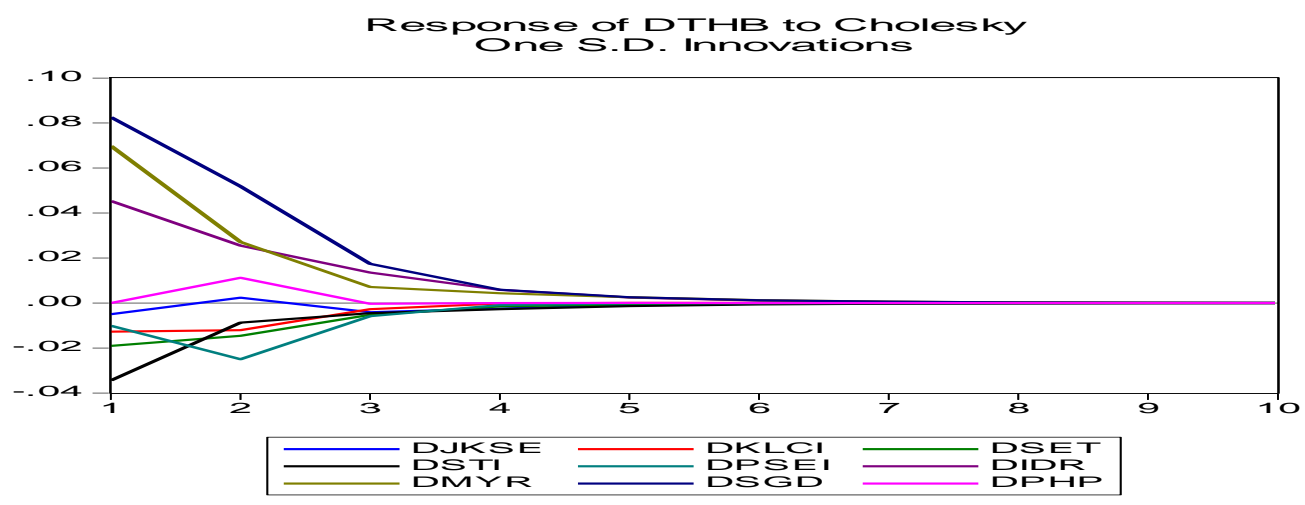

Figure 10. DTHB response

Based on Figure 11 above, it can be concluded that there is a shock of one standard deviation from DPHP, DSTI and DJKSE, responded to the Thai exchange rate (DTHB) in the two week period after the shock and shock of one standard deviation from DJKSE, DKLCI, DSET, DPSEI, DTHB, and DPSEI were responded to decrease in the second week period by DTHB. All indexes and exchange rates reach balance or return to their original state (before shocks) in the seventh week period.

\section{Response from DPHP}

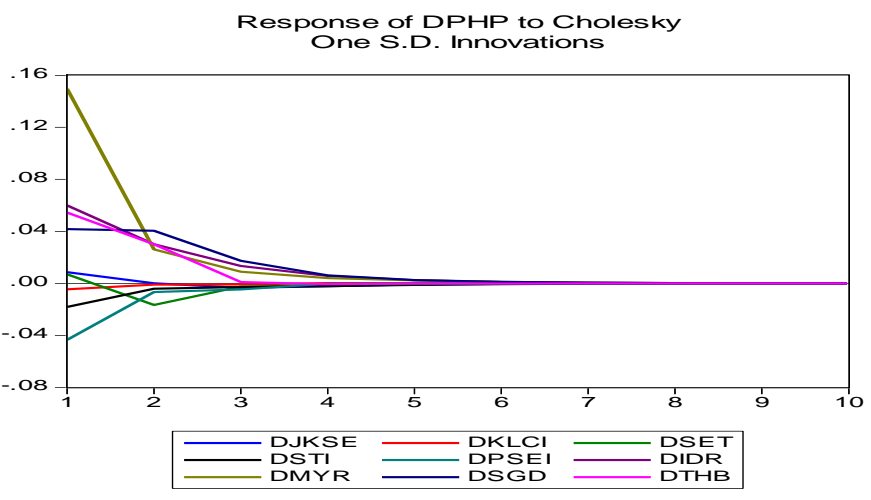

Figure 11. DPHP response

Based on Figure 12 above it can be concluded that the existence of a shock of one standard deviation from DKLCI, DSGD, DSTI and DJKSE, was responded to by the Philippine exchange rate (DPHP) in the period two weeks after the shock occurred. All indexes and exchange rates reach balance or return to their original state (before shocks) in the seventh week period.

But when viewed from the output of the Impulse Response Function (IRF), all variables indicate a response if there is a change in each index. The VAR model can be used to see the impact of changing one variable on another variable dynamically. The trick is to give a shock to one of the endogenous variables. The given shock is usually equal to 
one standard deviation of the variable (called innovations). Searching for the effects of shocks experienced by a variable on the value of all variables at present and in some future periods is called the Impulse Response Function (IRF) technique. Basically Impulse Response describes the path (path) where a variable will return to its balance after experiencing a shock (shock) from other variables. Every shock that occurs can be responded to on average for one week, after the shock occurs.

After analyzing dynamic behavior through impulse response, then the characteristics of the model will be seen through variance decomposition. Variance Decomposition (VD) provides information about the contribution of variables to one of the endogenous variables being observed in the VAR system analyzed.

Variance decomposition is used to compile a forecast error variance for a variable, namely how much the difference between the variance before and after the shock of both shocks originating from oneself and the shocks of other variables to see the relative influence of the research variables on other variables. Variance decomposition procedure is by measuring\% of surprises on each variable. From the result of Variance Decomposition (VD) it is stated that all variables contribute to the emergence of shocks on other variables.

Analysis Variance decomposition. After analyzing dynamic behavior through impulse response, then the characteristics of the model will be seen through variance decomposition. Variance Decomposition (VD) provides information about the contribution of variables to one of the endogenous variables being observed in the VAR system analyzed.

Variance decomposition is used to compile a forecast error variance for a variable, namely how much the difference between the variance before and after the shock of both shocks originating from oneself and the shocks of other variables to see the relative influence of the research variables on other variables. Variance decomposition procedure is by measuring $\%$ of surprises on each variable.

The following is presented the variance decomposition for the ten periods for each variable as follows:

a. The biggest movement of the Indonesian stock index JKSE is the contribution of the JKSE stock index itself which is equal to $81.12 \%$, while the lowest contribution is the Malaysian stock index (DKLCI) of only $0.11 \%$, this means for policy makers about the development of the Indonesian stock index , besides having to see the development of JKSE itself, it must also pay attention to the development of the Malaysian ringgit.

b. The biggest movement of the Malaysian stock index (KLCI) is the contribution of the KLCI stock index itself which is $81.62 \%$, while the other biggest variable contributing to the KLCI index is the movement of the Indonesian stock index (DJKSE) of $11.74 \%$.

c. The biggest movement of the Singapore STI stock index is the contribution of the STI stock index itself which is equal to $72.57 \%$, while the other biggest variable contributing to the Singapore stock index (STI) is the JKSE Indonesia stock index of $10.77 \%$.

d. The movement of the largest Thai SET stock index is the contribution of the Thai stock index (SET) itself that is equal to $79.72 \%$, while the other biggest variable contributing to the formation of the Thai stock index (DSET) is the JKSE Indonesia stock index of $11.65 \%$. 
e. The biggest movement of the PSEI Philippines stock index is the contribution of the Philippine stock index movement (DPSEI) itself which is equal to $61.51 \%$, while the other biggest variable contributing to the PSEI index is the JKSE Indonesia stock index of $23.46 \%$.

Co-integration Test. When the research variables are stationary at the same level, then the variables are indicated by a long-term relationship. The existence of a long-term relationship between variables can be proven by conducting a Co-integration (Johansen Co-integration) test. Johansen Co-integration testing is based on the VAR framework by entering error-correction. From the ten possible types of specifications in co-integration testing, the following table 2 and table 3 are co-integration test results with Johansen's method and can be seen in table 2 and table 3 that the trace value of statistics and eigenvalue is greater than the critical value at a significant level of $5 \%$, null hypothesis (H0) which stated that no co-integration is rejected and the alternative hypothesis (Ha) which stated that there is integration is accepted. Based on the above analysis, it can be stated that of the five variables in this study there is co-integration at a significant level of $5 \%$, so it can be concluded from ten variables that will form ten equations including DJKSE, DKLCI, DSTI, DSET, DPSEI. Co-integrated or integrated in the long term.

Table 2. Cointegration Rang Test (Trace) dan (Maximum Eigenvalue)

\begin{tabular}{|c|c|c|c|c|}
\hline $\begin{array}{l}\text { Hypothesized } \\
\text { No. of CE(s) }\end{array}$ & Eigenvalue & $\begin{array}{l}\text { Trace } \\
\text { Statistic }\end{array}$ & $\begin{array}{l}0.05 \\
\text { Critical Value }\end{array}$ & Prob.** \\
\hline None $*$ & 0.473703 & 3229.426 & 239.2354 & 1.0000 \\
\hline At most $1 *$ & 0.419784 & 2728.753 & 197.3709 & 1.0000 \\
\hline At most $2 *$ & 0.411001 & 2304.156 & 159.5297 & 1.0000 \\
\hline At most $3 *$ & 0.390075 & 1891.278 & 125.6154 & 1.0000 \\
\hline At most $4 *$ & 0.328608 & 1505.631 & 95.75366 & 1.0000 \\
\hline At most $5 *$ & 0.305542 & 1194.877 & 69.81889 & 1.0000 \\
\hline At most $6 *$ & 0.290063 & 910.4709 & 47.85613 & 0.0001 \\
\hline At most $7 *$ & 0.270734 & 643.2595 & 29.79707 & 0.0001 \\
\hline At most $8 *$ & 0.240907 & 397.0002 & 15.49471 & 0.0001 \\
\hline At most $9 *$ & 0.208118 & 182.0078 & 3.841466 & 0.0000 \\
\hline
\end{tabular}

Trace test indicates 10 cointegrating eqn(s) at the 0.05 level

* denotes rejection of the hypothesis at the 0.05 level

**MacKinnon-Haug-Michelis (1999) p-values

Table 3. Unrestricted Cointegration Rank Test (Maximum Eigenvalue)

\begin{tabular}{lllll}
\hline \hline $\begin{array}{l}\text { Hypothesized } \\
\text { No. of CE(s) }\end{array}$ & Eigenvalue & $\begin{array}{l}\text { Max-Eigen } \\
\text { Statistic }\end{array}$ & $\begin{array}{l}0.05 \\
\text { Critical Value }\end{array}$ & Prob.** \\
\hline \hline None $*$ & 0.473703 & 500.6734 & 64.50472 & 0.0001 \\
At most $1 *$ & 0.419784 & 424.5969 & 58.43354 & 0.0000
\end{tabular}




$\begin{array}{lllll}\text { At most } 2 * & 0.411001 & 412.8778 & 52.36261 & 0.0001 \\ \text { At most 3* } & 0.390075 & 385.6470 & 46.23142 & 0.0001 \\ \text { At most 4* } & 0.328608 & 310.7536 & 40.07757 & 0.0001 \\ \text { At most 5* } & 0.305542 & 284.4064 & 33.87687 & 0.0001 \\ \text { At most 6* } & 0.290063 & 267.2114 & 27.58434 & 0.0001 \\ \text { At most 7* } & 0.270734 & 246.2594 & 21.13162 & 0.0001 \\ \text { At most 8* } & 0.240907 & 214.9924 & 14.26460 & 0.0001 \\ \text { At most 9* } & 0.208118 & 182.0078 & 3.841466 & 0.0000\end{array}$

Max-eigenvalue test indicates 10 cointegrating eqn(s) at the 0.05 level

* denotes rejection of the hypothesis at the 0.05 level

**(MacKinnon-Haug-Michelis, 1999) p-values

\section{CONCLUSION}

Based on the analysis, it can be concluded, there has been ASEAN-5 stock market integration, with an asymmetric response. This is when there is a shock in the stock price in one of the ASEAN countries, then the stock price in the country will be responded other ASEAN countries.

The stock market in the ASEAN region influences and is influenced by other capital markets significantly, and all of these variables are indicated by a long-term relationship. The existence of a long-term relationship between variables can be proven by conducting a Co-integration (Johansen Co-integration) test. Johansen Co-integration testing is based on the VAR framework by entering error-correction.

The practical implications, from the result of this study, are useful for policy makers both regulators (governments) in the ASEAN region and investors can take decisions and towards diversifying international portfolios.

\section{REFERENCE}

Abdul Karim, B., and Xin Ning, H. (2013). Driving forces of the ASEAN-5 stock markets integration. Asia-Pacific Journal of Business Administration, 5(3), 186-191. https://doi.org/10.1108/APJBA-07-2012-0053.

BAILLIE, R. T., and BOLLERSLEV, T. (1994). Cointegration, Fractional Cointegration, and Exchange Rate Dynamics. The Journal of Finance, 49(2), 737-745. https://doi.org/10.1111/j.1540-6261.1994.tb05161.x.

Chen, J. H., and Chen, C. S. (2012). The study of contagious paces of financial crises. Quality and Quantity, 46(6), 1825-1846. https://doi.org/10.1007/s11135-011-95608.

Click, R., and Click, R. W. (2003). Stock Market Integration in ASEAN after the Financial Crisis.

Dillistone, A., Moreno, R., and Voisey, C. (2010). Market perspective. Proceedings of the 3rd Workshop on Mobile Video Delivery - MoViD '10, (26986), 69. https://doi.org/10.1145/1878022.1878028.

Goh, K. L., Wong, Y. C., and Kok, K. L. (2005). Financial crisis and intertemporal linkages across the ASEAN-5 stock markets. Review of Quantitative Finance and 
Accounting, 24(4), 359-377. https://doi.org/10.1007/s11156-005-7018-6.

$\mathrm{Kamal}^{*}$, J. Bin, and Haque, A. K. E. (2016). Dependence between stock market and foreign exchange market in South Asia: A Copula-Garch approach. The Journal of Developing Areas, 50 (1), 175-195. https://doi.org/10.1353/jda.2016.0010.

Kumar, R. (2016). Integration of Stock Returns and Volatility of Emerging Equity Markets. Review of Market Integration, 8(1-2), 79-102. https://doi.org/10.1177/0974929216687884.

Majdoub, J., and Mansour, W. (2014). Islamic equity market integration and volatility spillover between emerging and US stock markets. North American Journal of Economics and Finance, 29, 452-470. https://doi.org/10.1016/j.najef.2014.06.011.

Masson, P. (1999). Contagion: Macroeconomic models with multiple equilibria. Journal of International Money and Finance, 18(4), 587-602. https://doi.org/10.1016/S0261-5606(99)00016-9.

Roca, E. D., Selvanathan, E. A., and Shepherd, W. F. (1998). Are the ASEAN equity markets interdependent? ASEAN Economic Bulletin, 15(2), 109-120. Retrieved from http://www.jstor.org/stable/10.2307/25773519\%0Ahttp://www.jstor.org/discover/10. 2307/25773519 ?uid $=18761 \&$ uid=3738128\&uid=2\&uid=3\&uid=67\&uid=5911304\& uid=18760\&uid=62\&sid=21100926200491.

Thao, T. P., and Daly, K. (2012). The Impacts of the Global Financial Crisis on Southeast Asian Equity Markets Integration. International Journal of Trade Economics and Finance, 3(4), 299-304.

Thao, T. P., Daly, K., and Ellis, C. (2013). Assessing the Effects of the Global Financial Crisis on the East Asian Equity Markets. Emerging Markets and the Global Economy: A Handbook. Elsevier Inc. https://doi.org/10.1016/B978-0-12-4115491.00022-3.

Toda, H. Y., and Yamamoto, T. (1995). Statistical inference in vector autoregressions with possibly integrated processes. Journal of Econometrics. https://doi.org/10.1016/0304-4076(94)01616-8. 